\title{
IMPLEMENTASI SISTEM IMFORMASI MANAJEMEN DALAM MANAJEMEN SEKOLAH
}

Oleh

Wulan Rahma Safitri

Universitas Negeri Padang

Email: wulanrahma1998@gmail.com

\begin{abstract}
ABSTRAK
Artikel ini bertujuan untuk mengetahui bagaimana implementaasi sebuah Sistem Informasi Manajemen di dalam pengelolaan sekolah, untuk lebih memahami apa itu Sistem Informasi Manajemen kita harus tahu apa konsep Sistem Manajemen Sekolah itu, tujuan adanya Sistem Informasi Manajemen itu, dan manfaat Sistem Informasi Manajemen bagi sebuah organisasi, khususnya di dalam lembaga dunia pendidikan. Untuk itu para pemimpin, khususnya kepala sekolah mengetahui bagaimana cara menggunakan teknologi informasi saat ini mengingat teknologi sangat maju saat ini dan mengalami perubahan secara terus-menerus. Suatu pegambilan keputusan akan diproses melalui data dan dikumpulkan serta bagaimana data itu diproses. Data yang dikumpulkan oleh sebuah organisasi dan digali agar diproses untuk mendukung proses kemajuan organisasi. Hal ini sangat diperlukan mengingat proses manajerial dalam pengmbilan keputusan adalah hal yang sangat penting yang berguna bagi perancangan sistem informasi yang efektif.
\end{abstract}

Kata kuci: Implementasi, Sistem Informasi Manajemen, Manajemen

\section{Sekolah}

\section{PENDAHULUAN}

Peranan informasi dalam suatu organisasasi dan manajemen tidak perlu diragukan lagi. Informasi kini memegang peranan yang dominan, dalam suatu pengolahan, pendistribusian,penyimpanan dan penemuan kembali informasi sebuah 
organisasi. Tanpa adanya informasi para manajer, staf dan anggota karyawan tidak dapat mengambil keputusan secara efisien dan efektif dalam rangka mencapai tujuan organisasi.

Menurut (Gool , 2008)Para manajer, sebagai pelaksana fungsi, dalam rangka melaksanakan fungsi-fungsi manajemen yang ada di organisasi tentu dihadapkan pada keadaan yang dinamis dan kompleks atau sulit mengantisipasi apa yang akan terjadi dalam masa yang akan datang. Oleh karena itu, dalam rangka menjawab dan melaksanakan fungsi yang ada serta untuk mengurangi ketidak pastian pada masa yang akan datanv, para manajer perlu memahami dan menerapkan sistem informasi secara tepat. Artinya, manajer kompeten untuk menganalisis dan mengantisipasi resiko yang dapat merugikan organisasi dengan proaktif.

Untuk menghadapi hal-hal yang menguntungkan ataupun merugikan, para manajer, staf atau siapapun juga harus mempersiapkan diri untuk jangka pendek,menengah danjangka panjang supaya memiliki beberapa keterampilan dan keahlian seperti dibawah ini:

1. Keterampilan teknis ( Technical Skill), yaitu kemampuan untuk menggunakan pengetahuan akuntansi, keahlian penelitian, keahlian/keterampilan menggunakan komputer, metode dan alat atau benda-benda seperti mesin yang diperlukan untuk melakasanakan tugas-tugas khusus yang dapat diperoleh melalui pengalaman, pendidikan formal, pendidikan non formal dan pendidikan informal atau pendidikan seumur hidup, seperi membaca surat kabar, menonton televisi.

2. Keterampilan manusiawi (Human Skills), yaitu kemampuan keterampilan untuk mengadakan hubungan dengan manusia lainnya. Keterampilan ini harus dimiliki oleh seseorang staf/ manajer untuk dapat bekerja sama dengan orang lain, dan juga supaya dapat memotivasi orang lain supaya bersemangat bekerja dalam rangka untuk mencapai tujuan organisasi.

3. Keterampilan konseptual/ keterampilan manajemen, yaitu: kemapuan yang harus dimiliki oleh staf/para manjer untuk melihat, memahami serta menghayati bahgaimana keadaan organisasi secara keseluruhan, bagaimana menyusu rencana yang baik,bagaimana mengorganisasi, bagaimana memotivasi 
anggota/staf lainnya, bagaimana cara mengawasi/mengendalikan para staf yang berada di bawah pengawas/ pengendalian manajer tersebut.

Oleh karena itu Sistem Informasi Manajemen (SIM) sangat penting untuk menyeleseikan suatu permasalahan di dalam sebuah organisasi/ lembaga. Setiap manjemen harus bisa mengambil keputusan. Kepusan harus didasari dari informasi yang tepat, informasi itu dihasilkan dalam Sistem Informasi Manjemen.

\section{PEMBAHASAN}

\section{Konsep Dasar Sistem Informasi Manajemen}

Konsep dasar sistem informasi manaajemen (SIM) Menurut (Lipursari, 2013) adalah sebagai berikut:

a. Pengertian Sistem

Sistem merupakan suatu jaringan kerja dari prosedur yang saling berhubungan, berkumpul dan bersama-sama untuk melakukan suatu kegiatan atau untuk menyeleseikan suatu sasaran tertentu.

Suru sistem terdiri dari sejumlah komponen yang saling berinteraksi, saling bekerja sama membentuk satu kesatuan. Komponen-komponen sistem terdiri dapat berupa suatu sub sistem atau bagian-bagian dari sistem. Setiap sub sistem mempunyai sifat-sifat dari sistem untuk menjalankan suatu fungsi tertentu untuk mempengaruhi proses sistem secara keseluruhan.

Media penghubung antara satu sub sistem dengan sub sistem lainnya biasayan disebut dengan penghubung (intervace). Melalui penghubung ini memungkinkan sumber-sumber daya mengalir dari satu sub sistem ke sub sistem lainnya. Melalui penghubung keluaran (output) untuk sub sistem akan menjadi masukan (input) sub sistem lainnya. Dengan penghubung satu sub sistem dapat berinteraksi dengan sub sistem yang lainnya membentuk satu kesatuan.

Jadi, sistem adalah sekelompok komponen-komponen atau elemen-elemen yang dijadikan satu kesatuan untuk mencapai tujuan tertentu melalui sebuah interaksi. 


\section{b. Pengertian Informasi}

Data yang telah diklasifikasi atau diolah atau didinterprestasi untuk digunakan dalam proses pengambilan keputusan adalah informasi. Nilai informasi berhubungan dengan keputusan. Nilai informasi dilukiskan paling berarti dalam konteks sebuah keputusan. Bila tidak ada keputusan, maka informasi tidak diperlukan.

Fungsi utama informasi adalah menambah pengetahuan atau mengurangi ketidakpastian pemakai informasi. Informasi yang disampaikan kepada pemakai mungkin merupaka hasil data yang dimasukkan ke dalam dan pengolahan suatu model keputusan. Akan tetapi, dalam pengambilan keputusan yang kompleks, informasi hanya dapat menambah kemungkinan keputusan atau mengurangi bermacam-macam pilihan.

Adapun nilai-nilai informasi didasarkan atas 10 (sepuluh) sifat yaitu:

1) Mudah diperoleh

2) Luas dan lengkap

3) Ketelitian

4) Kecocokan

5) Ketepatan waktu

6) Kejelasan

7) Keluwesan

8) Dapat dibuktikan

9) Tidak ada prasangka

10) Dapat diukur

Jadi, informasi adalah sekumpulan data yang telah dibuktikan faktanya diamana data tersebut telah diproses dan dikelola sebaik mungkin sehingga menjadi sesuatu yang mudah dimengerti dan dapat bermanfaat bagi penerimanya.

\section{c. Pengertian Sistem Informasi Manajemen}

Menurt Moeljodihardjo dalam Sutabri (2005) Sistem Informasi Manajemen (SIM) adalah suatu metode untuk menghasilkan informasi yang tepat waktu bagi manajemen tentang lingkungan luar organisasi, dengan tujuan untuk menunjang proses pengambilan 
keputusan serta memperbaiki proses perencanaan da pengawasan. (Agustiandra \& Sabandi, 2019)

Menurut Gordon B. Davis (1984: 6) a definition of a management information system (MIS) as the term is generally understood, is an integrated, user machine system for providing information to support operations, managementand decision-making functions is an organizations. The system utilisez computer hardware and software, manual procedures, models for analysis, planning, control and decision making and a database. Ini mengandung pengertian yaitu Sistem Informasi Manajemen (SIM) adalah sebuah kesatua, sistem mesin pengguna yang teinntegrasi dalam memberikan informasi untuk mendukung operasi, manajemen san fungsi pembuatan keputusan dalam suatu organisasi. (Gool , 2008)

SIM merupakan sebuah sistem yang terdiri dari beberapa elemen/komponen yang saling berkaitan. Elemen-elemen/komponen dari sebuah sistem ini tentu saja akan saling terkoordinasi dengan baik agar dapat mencapai tujuan yang ingin dicapai. (Agustiandra \& Sabandi, 2019)

Sistem Informasi Manajemen adalah sebuah sistem informasi yang selain melakukan pengolahan transaksi yang sangat berguna untuk kepentingan organisasi, juga banyak memberikan dukungan informasi dan pengolahan untuk fungsi manajemen dalam pengambilan keputusan. (Gool , 2008)

Jadi, SIM adalah prosedur gabungan yang dijadikan menjadi satu dimana data yang didapatkan sudah dikumpulkan agar menghasilkan data yang andal, relevan, dan terorganisir dengan baik, yang mendukung dalam pengambilan keputusan di dalam sebuah orgnisasi.

\section{Tujuan Sistem Informasi Manajemen (SIM)}

Tujuan utama sistem informasi manajemen ialah membantu proses manajemen pada suatu organisasi. Manajemen meliputi seluruh hierarki manajemen puncak yang bertanggung jawab atas keberhasilan atau kegagalan organisasi secara keseluruhan hingga pada hierarki manajemen bawah yang hanya bertanggung jawab atas operasi sehari-hari dan departemen tertentu saja. (Gool , 2008) 
Tujuan dari sistem informasi adalah menghasilkan informasi. Informasi adalah data yang diolah menjadi bentuk yang berguna bagi para pemakainya. Untuk dapat berguna maka informasi harus didukung oleh tiga pilar sebagai berikut: tepat kepada orangnya atau relevan, tepat waktu dan tept nilainya atau akurat. (Purnama, 2016)

Semua organisasi membutuhka aliran informasi yang membantu manajer untuk mengambil bermacam keputusan yang dibutuhkan. Aliran informasi ini diatur dan diarahkan dalam suatu informasi. Sistem informasi berperan dalam proses pengambilan keputusan operasional harian sampai perencanaaan jangka panjang. Sebelum komputer ada, sistem informasi sudah menjadi kebutuhan organisasi. Ini berarti sistem informasi tidak selamnya berbasis komputer. Namun dengan berkembangnya fungsi komputer, sistem informasi saat ini umumnya didukung penuh oleh komputer. Sistem informasi organisasi digunakan untuk mendudukuung aktifitas-aktifitas organisasi berkembang dari masa ke masa. Tingkat keterlibatan sistem informasi organisasi makin lama makin luas dan dalam. (Purnama, 2016)

Jadi, tujuan sistem informasi manajemen adalah

1) Untuk menyediakan suatu informasi dalam pengambilan suatu keputusan.

2) Untuk menyediakan suatu informasi yang digunakan di dalam suatu proses manajemen di mulai daari perencanaan, pengendalian, pengevaluasian dan juga perbaikan berkelanjutan.

\section{Manfaat Sistem Informasi Manajemen( SIM)}

Keberhasilan suatu organisasi dalam mencapai tujuannya sangat tergantung pada kemampuan orang yang mengelola organisasi tersebut. Manajemen sebagai suatu metode yang mengatur, mengelola organisasi dapat diartikan sebaagai seni melaksanakan sesuatu melalui orang.

Dalam menjalankan tugasnya, para manajer memerlukan informasi, karena adanya perbedaan tugas maka informasi yang diperlukan juga akan berbeda. Perbedaan tersebut disebabkan oleh adanya periode waktu, tingkat ketidakpastian, tipe informasi, dasar kebutuhan informasi dan bentuk pelaporan. Sehingga dapat dikategorikan bahwa 
informasi adalah satu jenis sumber daya utama, dan termasuk dalam kategori sumber daya konseptual. (Purnama, 2016)

Pengembangan sistem informasi manajemen memerlukan sejumkah orang yang berketerampilan tinggi dan berpengalaman lama dan memerlukan partisipasi dari para manajer orgnisasi. Seistem informasi manaejemen yang mampu menyeimbangkan biaya dan manfaat yang akan diperoleh, arinya sistem informasi manajemen akan menghemat biaya, meningkatkan pendapatan serta tak terukur yang muncul dari informasi yang sangat bermanfaat.

Sistem informasi juga menyediakan informasi bagi pemakai dalam bentuk laporan dan output. Dalam organisasisistem informasi memiliki tiga tugas utama, yaitu mendukung kegiatan-kegiatan usaha/opersional, mendukung pengambilan keputusan manajemen, dan mendukung persaingan keuntungan strategis.

Jadi, manfaat sistem informasi manajemen (SIM) adalah:

1) Dapat menghasilkan suatu sistem, yang berguna untuk organisasi

2) Informasi lebih akurat

3) Membuat keputusan manajemen lebih terarah

4) Menjadikan informasi yang lebih bermanfaat bagi pihak organisasi

5) Menjamin aksebilitas data

\section{Implementasi Sistem Informasi Manajemen di Dalam Manajemen Sekolah}

Dalam rangka merencanakan atau mengkaji perlu atau tidaknya sebuah organisasi mengimplementasikan suatu sistem informasi dalam menunjanag pelaksanaan tugas-tugasnya, diperlukan analisis terkait faktor-faktor internal organisasi dan faktor eksternalnya. Hal ini diperlukan agar pada saat implementasinya dapat berjalandengan baik dan menghasilkan peningkatan kinerja atau keuntungan bagi organisasi tersebut.(Triwiyono \& Meirawan, 2013)

Kegiatan dalam lingkungan sekolah terutama dalam kegiatan belajar mengajar, sistem infomasi manajemen semakin berkembang dengan pesat karena adanya teknologi 
yang semakin canggih. Sekolah yang belum bia menerapkan SIM bisa dikatakan bahwa sekolah itu belum update dan masih ketinggalan zaman, karena semua kegiatan yang berhubungan dengan kegiatan sekolah lebih menguntungkan apabila menggunakan SIM. Contohnya, pada sistem penerimaan siswa baru, SIM dibutuhkan untuk memudahkan calon siswa untuk mendaftar ke sekolah tersebut, misalkan pendaftaraannya lewat sistem online. Pihak sekolah akan lebih mudah dalam menyimpan data calon siswa untuk diolah lebih lanjut ke dalam database. Memudahkan semua pihak berinteraksi, misalnya kepala sekolah dapat memberikan informasi kepada calon siswa maupun ke masyarakat dengan cara mengakses informasi tersebut dengan mudah. Segala informasi yang dibutuhkan oleh calon siswa/ masyarakat dapat dengan mudah diperoleh tanpa harus datang lansung ke sekolah itu dan cukup melihatnya di komputer dengan aplikasi SIM yang telah tersedia.

\section{REFERENSI}

Gool , C. J. (2008). Sistem Informasi Manajemen Pemahaman dan Aplikasi. SSJakarta: PT. Grasindo.

Purnama, C. (2016). Sistem Informasi Manajemen. Mojokerto: Insan Global.

Agustiandra, V., \& Sabandi, A. (2019). Persepsi Guru Terhadap Penerapan Sistem Informasi Manajemen Akademik Di Sekolah Menengah Kejuruan (Smk) Negeri 3 Padang. Jurnal Bahana Manajemen Pendidikan, 8(I), 1-8. Retrieved from http://ejournal.unp.ac.id/index.php/bahana/article/view/103704

Lipursari, A. (2013). Peran Sistem Informasi Manajemen (SIM) Dalam Pengambilan Keputusan. Jurnal STIE Semarang, 5(1), 26-37. https://doi.org/10.1017/CBO9781107415324.004

Triwiyono, D., \& Meirawan, D. (2013). Implementasi Sistem Informasi Manajemen Akademik Berbasis Teknologi Informasi Di Sekolah Dasar. Jurnal Administrasi Pendidikan UPI, 17(1), 61-72. 

